\title{
"The ability of cash flows to predict the earning: Evidence from Jordan"
}

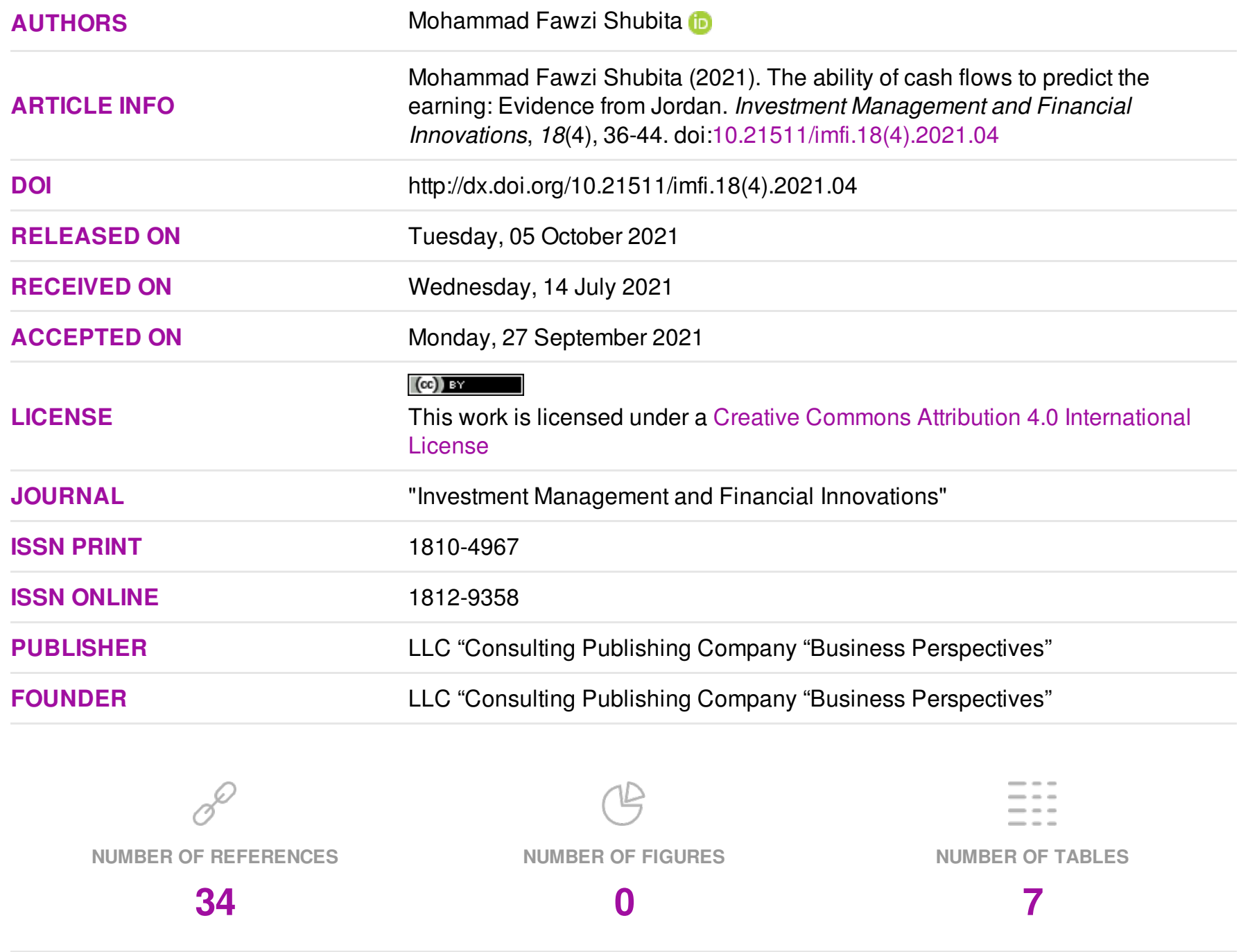

(C) The author(s) 2021. This publication is an open access article. 


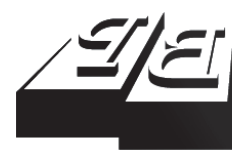

\section{BUSINESS PERSPECTIVES}

(O)

LLC "CPC "Business Perspectives" Hryhorii Skovoroda lane, 10, Sumy, 40022, Ukraine www.businessperspectives.org
Received on: $14^{\text {th }}$ of July, 2021 Accepted on: $27^{\text {th }}$ of September, 2021 Published on: $5^{\text {th }}$ of October, 2021

(C) Mohammad Fawzi Shubita, 2021

Mohammad Fawzi Shubita, Professor, Head of Accounting Department, Amman Arab University, Jordan.
This is an Open Access article, distributed under the terms of the Creative Commons Attribution 4.0 International license, which permits unrestricted re-use, distribution, and reproduction in any medium, provided the original work is properly cited.

Conflict of interest statement: Author(s) reported no conflict of interest

\section{THE ABILITY OF CASH FLOWS TO PREDICT THE EARNING: EVIDENCE FROM JORDAN}

\begin{abstract}
This study aims to investigate the ability of cash flows components to predict the earning and to know the extent of the relationship between accounting profits and cash flow measures. The study sample consisted of 77 industrial companies listed on the Amman Stock Exchange in Jordan for the period from 2006 to 2019. This study relied on the regression method to test the relationship between the study variables. The study findings showed that the cash flows from operating, investing, and financial activities have a statistically significant impact on predicting future earnings. The study also examined the effect of length of operating cycle and company's size on the predictive ability of cash flows regarding future earnings. The main results for this aspect are that large companies and short operating cycle companies have higher prediction ability for future earnings than small and long operating cycle companies. This paper provides evidence of the information content of cash flows for future earnings in emerging markets like Jordan and is important for Jordanian shareholders by enabling them to evaluate company's performance.
\end{abstract}

Keywords information content, market analysis, cash flow, earnings, Jordan

JEL Classification M41, M40, G10

\section{INTRODUCTION}

According to the conceptual framework of the International Accounting Standards Board, the financial report aims to provide financial information about the firm that is important to current and prospective creditors, lenders, and other investors in making various economic decisions. For this, the accounting information should be relevant because it can make a difference in the decisions made by the users if it involves a predictive value, an assertive value, or both (IASB, 2020).

This paper investigates the ability of cash flow components to predict firm earnings. The cash flow statement helps its users in making rational economic decisions by providing them with a sound basis for evaluating the facility's ability to obtain cash, how to obtain it, when to obtain it, and the degree of certainty associated with obtaining it (Shubita, 2019).

Accounting data has predictive value if it can be used as input into various models for forecasting future results. Users of financial statements need information that helps them to evaluate the expected returns from the decisions they make, as well as the risks surrounding them. Accounting data have a confirmatory value if they provide feedback on previous evaluations, by reinforcing or refuting the previously reached assessments. In some cases, users of financial statements make decisions based on prior predictions, and here is the role of relevant information in confirming those decisions. 
Accounting information reported by companies is important in forecasting future earnings for making sound financial decisions. Forecasting future earnings with information obtained from accounting reports aids in the securities valuation, facilitating the process of decision-making and valuing the credit in a firm to ensure the solvency and profitability of a company, and evaluating investments from the short-term and long-term perspectives.

Cash flows from operating activities are the cash flows generated from the main activities of the enterprise. The cash flows from investing activities express the extent of expenditure that the enterprise has made to obtain the necessary resources to generate future income and cash flows. Cash inflows and outflows for financing activities include cash flows related to obtaining owners' money and paying returns on their investments, as well as borrowing and repaying funds, and obtaining any long-term creditors' amounts that have been repaid (Ahmed et al., 2021).

The study problem is that the cash flows serve a vital role in estimating the size of future earnings. The statement of cash flows gives information on activities and therefore it helps the firm's ability to generate future operating cash flows by evaluating its ability to generate cash flows, cover all operating activities, and meet obligations. In the absence of a study on the relative forecasting ability of cash flows components for future earnings in emerging markets like Jordan, this study investigates this issue and takes into consideration the impact of firm characteristics such as length of operating cycle and firm size.

\section{LITERATURE REVIEW AND HYPOTHESES DEVELOPMENT}

The cash flow statement is considered as the appropriate tool for the institution to measure its financial position and by comparing it with other financial statements. The cash flow statement is considered relatively recent, and since its inception to thousands, it has witnessed a remarkable development, both in terms of the inputs used in its preparation or in terms of images or models for its presentation or in terms of the strength of the rules it is required to publish (Mulenga \& Bhatia, 2017).

In particular, several types of studies documented that earnings are better than current operating cash flows in predicting future operating cash flows (e.g., Arnedo et al., 2012; Nam et al., 2012; Kim \& Kross, 2005; Greenberg et al. 1986), while other studies documented the opposite (e.g., Chen et al., 2017; Efayena, 2015; Finger, 1994; Bowen et al.,1986).

Call (2008) showed that financial analysts publish their cash flow forecasts as the main tool for controlling income and disclosing information by firms, which improves the predictive ability of fu- ture operating cash flows. The extraordinary cash flows significantly decrease in the year following the issuance of financial analysts' estimation of operating cash flows.

Call et al. (2009) also showed that financial analysts' forecasting of earnings is more accurate if it is accompanied by operating cash flows, whereas financial analysts understand the characteristics of the time series of earnings and their components when they link cash flows and earnings.

Sharawi (2021) examines the role of accrual accounting in the expected cash flow in comparison with the current cash flow of companies in Egypt and Saudi Arabia. Using regression models, the study found that both operating cash flow and net income have the predictive ability in both countries but operating cash flow is a better predictor of expected operating cash flows than the net income.

Pimentel and Malacrida (2020) investigated 270 Brazilian companies listed from 2005 to 2018 and found that high accrual levels are related to lower future income, the accruals positively affect the earnings, and net income has the incremental predictive ability to explain future cash flows from operating activities. 
Nguyen and Nguyen (2020) evaluated the predictive power of operating cash flows by using historical income and cash flows information for the listed companies on Ho Chi Minh City Stock Exchange from 2009 to 2018. The results indicated that cash flows and earnings had a significant ability to expect future cash flows. In addition, the study also reached the conclusion that the operating cash flows models, which combined with accruals, had the most effective prediction power.

Hussain et al. (2020) examined the impact of the global financial crisis on this relationship between future operating cash flow prediction and accruals of 453 companies from the period from 1999 to 2018. Regression models are used to examine the association between the estimation of future cash flows, disaggregated accruals, and accruals. The study found that non-trading accruals, financial accruals, and total aggregated accruals were significant contributors to the future operating cash flows estimation.

Ragab and Hani (2018) choose the Lebanese and Egyptian banking firms due to the important role they play in the region. The study results supported the value relevance of cash flows in banks and that the bank size had a moderating impact on the association between operating cash flows and stock prices.

Larson et al. (2018) investigate three important roles for accruals. First, to reflect the asymmetric recognition of company losses. Second, to determine investments related to the scale of firm operations growth. Third, to alleviate timing differences between associated cash flows impacts and economic events.

Hui et al. (2016) provide a tool for estimating the future performance of companies (in terms of operating cash flows and earnings) by the understanding of the time-series dynamics of cash flows and earnings. This issue has important practical relevance for estimation biases and disappointing accuracy.

Zhou et al. (2010) aimed to use an indicator of good lighting to predict financial hardship represented in transferring money and deficits, saving money to prevent further deterioration and re- duce risks and the possibility of bankruptcy. The study was conducted on a sample of 48 companies listed on the Shanghai Stock Exchange, and their data is collected from the original financial markets published from the financial year 2006 to the financial year 2008 .

This study aims to clarify the cash flow's ability to predict the future earnings, by explaining the cash flow's ability role to predict the future earnings of the industrial firms listed on the Amman Stock Exchange.

The study hypotheses are:

$H_{01}$ : Operating cash flow does not have a significant relationship with future income.

$H_{02}$ : Investing cash flow does not have a significant relationship with future income.

$H_{03}$ : Financing cash flow does not have a significant relationship with future income.

\section{METHODOLOGY}

\subsection{Empirical model}

To test the hypotheses of the study, a statistical model was relied upon largely based on AlHawatmeh (2020) study. Net income and operating income will be used to measure the dependent variable (Dechow, 1994).

The study models are:

$$
\begin{aligned}
& I N C_{i t}=\alpha+\beta_{1} O C F_{i t}+\beta_{2} I C F_{i t}+ \\
& +\beta_{3} F C F_{i t}+\varepsilon,
\end{aligned}
$$

where $\alpha, \beta_{1}, \beta_{2}, \beta_{3}-$ model coefficients, $\varepsilon$ model error, $i$ - firm, $t$ - year, $O C$ - Length of the operating cycle.

Regarding the earnings (dependent variable), operating income is used. To reduce the heteroscedasticity impact the whole study variables were divided by average total assets (Habib, 2010; Luc, 2018).

The variables of the study were the following: ten dependent variables (financial) and independent 
variables (rate of coverage of the two, rate of coverage of current liabilities, rate of coverage of cash stock, the rate of cash return to normal operating income, ratio of cash return to total equity, rate of return of cash to equity of shareholders, average net profit rate, the rate of cash return to the net operating profit, the proportion of the flows resulting from operating activities, the proportion of the flows resulting from investment activities, the proportion of the flows resulting from financing activities). The application of these two indicators of cash flows and these indicators of financial hardship, which confirms the importance and safety of relying on cash flow indicators in forecasting financial hardship.

The sample includes Jordanian industrial companies listed on the annual financial statements of the Amman Stock Exchange between 2005 and 2019. The data is obtained from Amman Stock Exchange websites. The total observations are 738 company-year observations. The importance of choosing the Jordanian industrial sector is due to the important role it plays for Jordanian economic development.

\section{RESULTS}

Table 1 shows the main variable descriptive measures for the industrial Jordanian companies; the industrial sector is important in Jordan, it had a high contribution margin in the Gross Domestic Product. Table 1 shows that the Jordanian industrial companies in total generate losses but on other hand generate positive operating income.

Panel A is for the total companies' observations and indicates that the operating cash flow in Jordanian companies is positive, which is considered a good sign and means those Jordanian industrial companies can generate cash by their operating essential activities. The negative sign for cash flow from investing activities means that the Jordanian industrial companies invest in purchasing fixed assets to expand their works. Lastly, the negative cash flow from financial activities can mean either that the companies reduce their capital or, the more probable option, indicates that these companies pay their long-term obligations.

The other panels give the same indications for the cash flow signs but it differs as expected in the net income and operating income because large companies and short operating cycle companies generate profit, but on the other hand, small companies and long operating cycle companies generate losses.

The total companies' panel indicates that Jordanian industrial companies need 477 days on average to convert cash-to-cash (operating cycle), this high figure will lead to liquidity problems. To study this important characteristic the study sample is divided into short operating cycle companies (the

Table 1. Descriptive statistics

\begin{tabular}{|c|c|c|c|c|c|}
\hline & \multirow{2}{*}{ Mean } & \multirow{2}{*}{ Median } & \multirow{2}{*}{ STD } & \multicolumn{2}{|c|}{ Percentile } \\
\hline & & & & 25 & 75 \\
\hline Panel A & \multicolumn{5}{|c|}{ All observation $(\mathrm{N}=738)$} \\
\hline$N I$ & -0.0088 & 0.0074 & 0.125 & -0.0586 & 0.0531 \\
\hline$O I$ & 0.0008 & 0.0116 & 0.126 & -0.0498 & 0.0566 \\
\hline$O C F$ & 0.0381 & 0.0383 & 0.1177 & -0.0225 & 0.0990 \\
\hline ICF & -0.025 & -0.0138 & 0.7914 & -0.0431 & 0.099 \\
\hline FCF & -0.0126 & -0.0166 & 0.1183 & -0.0632 & 0.0213 \\
\hline$O C$ & 477 & 266 & 1235 & 176 & 430 \\
\hline Total assets & $63,328,517$ & $15,751,215$ & $177,959,970$ & $8,156,644$ & $44,190,777$ \\
\hline Panel B & \multicolumn{5}{|c|}{ Operating cycle (Short) $(\mathrm{N}=276)$} \\
\hline NI & 0.0278 & 0.0306 & 0.11901 & -0.0047 & 0.0757 \\
\hline Ol & 0.040 & 0.0397 & 0.1118 & -0.0082 & 0.0831 \\
\hline$O C F$ & 0.0666 & 0.0678 & 0.1172 & -0.0008 & 0.1224 \\
\hline ICF & -0.0379 & -0.0263 & 0.08762 & -0.060 & -0.0078 \\
\hline FCF & -0.0230 & -0.0292 & 0.11476 & -0.0767 & 0.0164 \\
\hline$O C$ & 156 & 157 & 46 & 120 & 196 \\
\hline Total assets & $113,439,063$ & $22,214,000$ & $25,540,000$ & $11,304,292$ & $70,682,437$ \\
\hline
\end{tabular}


Table 1 (cont.). Descriptive statistics

\begin{tabular}{|c|c|c|c|c|c|}
\hline & \multirow{2}{*}{ Mean } & \multirow{2}{*}{ Median } & \multirow{2}{*}{ STD } & \multicolumn{2}{|c|}{ Percentile } \\
\hline & & & & 25 & 75 \\
\hline Panel C & \multicolumn{5}{|c|}{ Operating cycle (Long) $(\mathrm{N}=\mathbf{2 7 6}$ ) } \\
\hline$N I$ & -0.0318 & -0.0177 & 0.1047 & -0.0843 & 0.383 \\
\hline Ol & -0.0205 & -0.0073 & 0.10252 & -0.0712 & 0.0427 \\
\hline$O C F$ & 0.0192 & 0.0221 & 0.10502 & -0.0330 & 0.0704 \\
\hline ICF & -0.0161 & -0.0091 & 0.0753 & -0.0245 & -0.0557 \\
\hline FCF & -0.0037 & -0.0112 & 0.10388 & -0.0557 & .0342 \\
\hline$O C$ & 900 & 497 & 1873 & 388 & 686 \\
\hline Total assets & $26,625,875$ & $13,124,359$ & $42,794,835$ & $5,952,680$ & $25,637,397$ \\
\hline Panel D & \multicolumn{5}{|c|}{ Small firms ( $N=293)$} \\
\hline$N I$ & -0.0438 & -0.0183 & 0.1478 & -0.1065 & 0.0354 \\
\hline $\mathrm{Ol}$ & -0.0432 & -0.0275 & 0.1552 & -0.093 & 0.0398 \\
\hline OCF & 0.0225 & 0.0121 & 0.1378 & -0.0505 & 0.099 \\
\hline ICF & -0.0131 & -0.0078 & 0.081 & -0.305 & -0.002 \\
\hline FCF & -0.0096 & -0.0065 & 0.1305 & -0.055 & 0.018 \\
\hline$O C$ & 606 & 318 & 1558 & 201 & 536 \\
\hline Total assets & $6,326,343$ & $6,534,816$ & $3,506,142$ & $2,770,713$ & $94,606,754$ \\
\hline Panel E & \multicolumn{5}{|c|}{ Large firms ( $\mathrm{N}=295$ ) } \\
\hline$N I$ & 0.0244 & 0.0198 & 0.1045 & -0.0213 & 0.0686 \\
\hline OI & 0.039 & 0.0278 & 0.0941 & -0.0063 & 0.0739 \\
\hline OCF & 0.0548 & 0.0552 & 0.1063 & -0.0046 & 0.1059 \\
\hline ICF & -0.037 & -0.0181 & 0.0847 & -0.0609 & -0.0039 \\
\hline FCF & -0.0179 & -0.031 & 0.112 & -0.0708 & 0.0213 \\
\hline$O C$ & 401 & 229 & 1172 & 153 & 366 \\
\hline Total assets & $144,208,462$ & $59,614,779$ & $26,160,000$ & $27,890,413$ & $88,325,728$ \\
\hline
\end{tabular}

lowest $40 \%$ from the total companies) and long operating cycle (the highest $40 \%$ ).

The short operating cycle companies need only 156 days comparing with 900 days for long-term operating cycle companies to convert cash to cash.

Lastly, the study divides the study sample companies into small and large companies based on the lowest and highest $40 \%$ of total assets respectively as explained in panels $\mathrm{D}$ and $\mathrm{E}$. Large companies can invest their assets to generate more cash flow from operating activities.

Table 2. Correlation matrix

\subsection{Bivariate Correlation}

Table 2 gives indicators about the correlation coefficients for the main variables of the study, net income, and operating income have the highest correlation factor $(90.8 \%)$ so these two variables are not be put in the same model to avoid the multicollinearity problem. It shows that the companies with high operating and net income have lower operating cycles compared to other companies. Profitable companies can shorten the operating cycle to enhance their liquidity position.

\begin{tabular}{|c|c|c|c|c|c|c|}
\hline Variable & $\mathrm{NI}$ & OI & OCF & ICF & $F C F$ & $O C$ \\
\hline$\overline{O I}$ & $0.908 * *$ & & & & & \\
\hline OCF & $0.401^{* *}$ & $0.42^{* *}$ & & & & \\
\hline ICF & $-0.244^{* *}$ & $-0.296^{* *}$ & $-0.268^{* *}$ & & & \\
\hline FCF & $-0.117^{* *}$ & $-0.096^{* *}$ & $-0.609 * *$ & $0.384 * *$ & & \\
\hline$O C$ & $-0.106^{* *}$ & $-0.12^{* *}$ & $-0.088^{*}$ & $-0.085^{*}$ & $0.142^{* *}$ & \\
\hline Total assets & $0.208^{* *}$ & $0.216^{* *}$ & $0.157 * *$ & $0.100 *$ & $-0.093^{*}$ & -0.064 \\
\hline
\end{tabular}

Note: * means significant at $0.05 ;{ }^{* *}$ means significant at 0.01 . 
The inverse relationship between cash flow from operating activities from one side and cash flow from investing and financing activates from the other side means that the Jordanian industrial companies use the operating cash flow in expanding their investments in long-term assets and in decreasing their long-term obligation, which decreases the financing cost.

\section{DISCUSSION}

The findings of the analysis of variance of the research model were estimated based on the financial reports of the Jordanian industrial firms. Operating income and net income are used as dependent variables in the study, but because oper- ating income gives better indicators than the net income, it will be used in this study as an earning indicator.

Tables 3 to 7 lead to the acceptance of the three hypotheses of this study. Therefore, operating cash flows have a statistically significant impact on predicting future earnings, investing cash flows have a statistically significant impact on predicting future earnings, and financing cash flows have a statistically significant impact on predicting future earnings.

These findings come from the adj- $R^{2}$ from Table 3 as it was $21.8 \%$, which means that the model's three independent variables can explain $21.8 \%$ of the earnings variation.

Table 3. OLS regression results

\begin{tabular}{|c|c|c|c|c|}
\hline Variable & Coefficients & Errors & $t$ & Sig. \\
\hline Constant & -0.021 & & -4.762 & 0.000 \\
\hline OCF & 0.530 & 0.060 & 8.777 & 0.000 \\
\hline ICF & -0.158 & 0.077 & -2.048 & 0.041 \\
\hline FCF & 0.179 & 0.063 & 2.848 & 0.005 \\
\hline$R^{2}$ & 0.221 & \multicolumn{2}{|c|}{ Adj $R^{2}$} & 0.218 \\
\hline F-Statistics & 69.341 & \multicolumn{2}{|c|}{ Sig } & 0.000 \\
\hline VIF & 3.259 & \multicolumn{2}{|c|}{ Durbin-Watson } & 1.155 \\
\hline
\end{tabular}

Table 4. OLS regression results (large companies)

\begin{tabular}{|c|c|c|c|c|}
\hline Variable & Coefficients & Errors & $t$ & Sig. \\
\hline Constant & 0.009 & & 1.813 & 0.071 \\
\hline OCF & 0.636 & 0.076 & 8.399 & 0.000 \\
\hline ICF & 0.076 & 0.094 & 0.807 & 0.421 \\
\hline FCF & 0.137 & 0.084 & 1.624 & 0.106 \\
\hline$R^{2}$ & 0.383 & \multicolumn{2}{|c|}{$\operatorname{Adj} R^{2}$} & 0.376 \\
\hline F-Statistics & 60.142 & \multicolumn{2}{|c|}{ Sig } & 0.000 \\
\hline VIF & 4.771 & \multicolumn{2}{|c|}{ Durbin-Watson } & 1.354 \\
\hline
\end{tabular}

Table 5. OLS regression results (small companies)

\begin{tabular}{|c|c|c|c|c|}
\hline Variable & Coefficients & Errors & $t$ & Sig. \\
\hline Constant & -0.056 & & -6.679 & 0.000 \\
\hline$O C F$ & 0.447 & 0.096 & 4.665 & 0.000 \\
\hline ICF & -0.351 & 0.134 & -2.621 & 0.009 \\
\hline FCF & 0.237 & 0.099 & 2.390 & 0.017 \\
\hline$R^{2}$ & 0.200 & \multicolumn{2}{|c|}{$\operatorname{Adj} R^{2}$} & 0.191 \\
\hline F-Statistics & 24.033 & \multicolumn{2}{|c|}{ Sig } & 0.000 \\
\hline VIF & 2.611 & \multicolumn{2}{|c|}{ Durbin-Watson } & 1.222 \\
\hline
\end{tabular}


Table 6. OLS regression results (long operating cycle companies)

\begin{tabular}{|c|c|c|c|c|}
\hline Variable & Coefficients & Errors & $t$ & Sig. \\
\hline Constant & -0.028 & & -4.694 & 0.000 \\
\hline OCF & 0.225 & 0.100 & 2.253 & 0.025 \\
\hline ICF & -0.204 & 0.113 & -1.816 & 0.071 \\
\hline FCF & -0.056 & 0.104 & -0.539 & 0.590 \\
\hline$R^{2}$ & 0.108 & \multicolumn{2}{|c|}{ Adj $R^{2}$} & 0.098 \\
\hline F-Statistics & 10.980 & \multicolumn{2}{|c|}{ Sig } & 0.000 \\
\hline VIF & 3.372 & \multicolumn{2}{|c|}{ Durbin-Watson } & 1.093 \\
\hline
\end{tabular}

Table 7. OLS regression results (short operating cycle companies)

\begin{tabular}{|c|c|c|c|c|}
\hline Variable & Coefficients & Errors & $t$ & Sig. \\
\hline Constant & 0.002 & & 0.286 & 0.775 \\
\hline OCF & 0.584 & 0.086 & 6.807 & 0.000 \\
\hline ICF & -0.054 & 0.108 & -0.499 & 0.618 \\
\hline FCF & 0.122 & 0.096 & 1.277 & 0.203 \\
\hline$R^{2}$ & 0.325 & \multicolumn{2}{|c|}{ Adj $R^{2}$} & 0.317 \\
\hline F-Statistics & 43.566 & \multicolumn{2}{|c|}{ Sig } & 0.000 \\
\hline VIF & 3.903 & \multicolumn{2}{|c|}{ Durbin-Watson } & 1.344 \\
\hline
\end{tabular}

\section{CONCLUSION}

The purpose of this study is to verify the ability to operate, invest, and finance cash flows to predict earnings. The main results obtained from this study showed a strong relationship between the cash flows components and future profits and that large companies and short operating cycle companies have higher prediction ability for future earnings than small and long operating cycle companies.

These findings are vital to shareholders by enabling them to evaluate the firm liquidity, risks, and resilience, and their ability to expect the earning because cash flow prediction is the most useful and important factor required in several economic decisions like the lending decision, investment decision, and other financial decisions by accounting users. It helps them in evaluating the company's financial flexibility, liquidity, and risks. The prediction of earnings and the availability of a suitable level of cash to the company is important. This is because a company can be generating profit but suddenly go insolvent if it cannot obtain cash. For companies, the timing of cash inflows and when it will be invested as well as when cash can be distributed back to the stakeholders as a dividend is of important concern.

The study recommends mandating the forecast to the decision-making process so the companies' managers should enhance the staff professional skills in cash flow predicting and put the cash flows ratios to the financial statements supplementary notes to inform the financial data users.

\section{AUTHOR CONTRIBUTIONS}

Conceptualization: Mohammad Fawzi Shubita.

Data curation: Mohammad Fawzi Shubita.

Formal analysis: Mohammad Fawzi Shubita.

Funding acquisition: Mohammad Fawzi Shubita.

Investigation: Mohammad Fawzi Shubita.

Methodology: Mohammad Fawzi Shubita.

Project administration: Mohammad Fawzi Shubita.

Resources: Mohammad Fawzi Shubita.

Software: Mohammad Fawzi Shubita. 
Supervision: Mohammad Fawzi Shubita.

Validation: Mohammad Fawzi Shubita.

Visualization: Mohammad Fawzi Shubita.

Writing - original draft: Mohammad Fawzi Shubita.

Writing - review \& editing: Mohammad Fawzi Shubita.

\section{ACKNOWLEDGMENTS}

I would like to thank Amman Arab University for its great support, and for funding this study.

\section{REFERENCES}

1. Ahmed, W., Khan, H. H., Rauf, A., Ulhaq, S., Bano, S., Sarwar, B., Huda, S., Khan, M., Wali, A., \& Durrani, M. N. (2021). Simultaneous Equation Estimation in Finance and Corporate Financial Decision: Empirical Evidence from Pakistan Stock Exchange. The Journal of Asian Finance, Economics and Business, 8(3), 11-21. https://doi. org/10.13106/jafeb.2021.vol8. no3.0011

2. Al-Deb'i, M. A. M. (2011). Are Operating Cash Flows a Superior Predictor of Future Operating Cash Flows than Earnings? Evidence from Jordan. European Journal of Economics, Finance and Administrative Sciences, 40, 36-46. Retrived from https:// www.researchgate.net/publication/284028979

3. Al-Debie, M. M. (2011). Working capital management and profitability: the case of industrial firms in Jordan. European Journal of Economics, Finance and Administrative Sciences, 36, 75-86. Retrieved from https://www.researchgate. net/profile/Mamoun-Al-Debie/ publication/284029352_Working_Capital_Management_and_ Profitability_The_Case_of_Industrial_Firms_in_Jordan/ links/57ecef7108ae92a5dbd08885/ Working-Capital-Managementand-Profitability-The-Case-ofIndustrial-Firms-in-Jordan.pdf

4. Al-Hawatmeh, O. M. (2020). The ability of cash flows to predict the earning. Journal of Social Sciences, 9(2), 590-602. https://doi. org/10.25255/jss.2020.9.2.590.602
5. Arnedo, L., Lizarraga, F., \& Sanchez, S. (2012). The role of accounting accruals for the prediction of future cash flows: evidence from Spain. SERIE, 3, 499-520. https://doi.org/10.1007/ s13209-011-0070-7

6. Barth, M. E., Cram, D. P., \& Nelson, K. K. (2001). Accruals and the prediction of future cash flows. The Accounting Review, 76(1), 27-58. https://doi.org/10.2308/ accr.2001.76.1.27

7. Bowen, R. M., Burgstahler, D., \& Daley, L. A. (1986). Evidence on the relationships between earnings and various measures of cash flow. The Accounting Review, 61(4), 713-725.

8. Call, A. C. (2008). Analysts' cash flow forecasts and the predictive ability and pricing of operating cash flows. SSRN.

9. Call, A. C., Chen, S., \& Tong, Y. H. (2009). Are analysts' earnings forecasts more accurate when accompanied by cash flow forecasts? Review of Accounting Studies, 14(2-3), 358-391. http:// dx.doi.org/10.1007/s11142-0099086-7

10. Charitou, A., Clubb, C., \& Andreou, A. (2001). The effect of earnings permanence, growth, and firm size on the usefulness of cash flows and earnings in explaining security returns: empirical evidence for the UK. Journal of Business Finance \& Accounting, 28(5-6), 563-594. https://doi. org/10.1111/1468-5957.00385

11. Chen, C. W., Melessa, S., Mergenthaler, R. D., \& Ohn, H. (2017).
Revisiting Measurement Error in Surrogate Measures of Operating Cash Flows: Have We Solved the Problem? SSRN. https://doi. org/10.2139/ssrn.3075461

12. Dechow, P. M. (1994). Accounting earnings and cash flows as measures of firm performance: The role of accounting accruals. Journal of Accounting and Economics, 18(1), 3-42. https://doi.org/10.1016/01654101(94)90016-7

13. Dechow, P. M., Kothari, S. P., \& Watts, R. L. (1998). The relation between earnings and cash flows. Journal of Accounting and Economics, 25(2), 133-168. https://doi.org/10.1016/s01654101(98)00020-2

14. Efayena, O. (2015). The role of accrual accounting basis in the prediction of future cash flows: The Nigerian evidence. Research Journal of Finance and Accounting, 6(4), 171-180. Retrieved from https://tarjomefa.com/wpcontent/uploads/2017/08/7530English-TarjomeFa.pdf

15. Finger, C.A. (1994). The ability of earnings to predict future earnings and cash flows. Journal of Accounting Research, 32(2), 210-223. https://doi. org/10.2307/2491282

16. Greenberg, R.R., Johnson, G.L., \& Ramesh, K. (1986). Earnings versus cash flows as a predictor of future cash flow measures. Journal of Accounting, Auditing and Finance, 1(4), 266-277. https://doi. org/10.1177/0148558x8600100402

17. Habib, A. (2010). Prediction of operating cash flows: 
Further evidence from Australia. Australian Accounting Review, 20(2), 134-143. https:// doi.org/10.1111/j.18352561.2010.00086.x

18. Hayn, C. (1995). The information content of losses. Journal of Accounting and Economics, 20(2), 125-153. https://doi. org/10.1016/0165-4101(95)00397-2

19. Hui, K. W., Nelson, K. K., \& Yeung, P. E. (2016). On the persistence and pricing of industry-wide and firm-specific earnings, cash flows, and accruals. Journal of Accounting and Economics, 61(1), 185-202. https://doi.org/10.1016/j. jacceco.2015.06.003

20. Hussain, R. I., Abidin, N. S. Z., Ibrahim, F., \& Joginder, J. S. (2020). Accruals in the prediction of forthcoming cash flows in the companies listed at Pakistan stock exchange. International Journal of Economics and Financial Issues, 10(5), 130-139. https://doi. org/10.32479/ijefi.10313

21. IASB. (2020). IFRS standards as issued at 2020, the conceptual framework for financial reporting. London: IFRS Foundation.

22. Jabr, J. Z., \& Al-Debie, M. M. (2008). The Effect of the Sign of Accounting Earnings and Operating Cash Flows on Their Information Content. Jordan Journal of Business Administration, 4, 1-23. Retrieved from https:// journals.ju.edu.jo/JJBA/article/ view/715

23. Kim, M., \& Kross, W. (2005). The ability of earnings to predict future operating cash flows has been increasing - not decreasing. Journal of Accounting Research, 43(5), 753-780. https://doi.org/10.1111/j.1475679x.2005.00189.x

24. Larson, C. R., Sloan, R., \& Giedt, J. Z. (2018). Defining, measuring, and modeling accruals: a guide for researchers. Review of Accounting Studies, 23(3), 827-871. http://doi. org/10.1007/s11142-018-9457-z

25. Luc, P. T. (2018). The relationship between perceived access to finance and social entrepreneurship intentions among university students in Vietnam. The Journal of Asian Finance, Economics, and Business, 5(1), 63-72. https://doi. org/10.13106/jafeb.2018.vol5. no1.63

26. Mulenga, M., \& Bhatia, M. (2017). The review of literature on the role of earnings, cash flows and accruals in predicting of future cash flows. Accounting and finance research, 6(2), 59-70. http://dx.doi. org/10.5430/afr.v6n2p59

27. Nam, S., Brochet, F., \& Ronen, J. (2012). The predictive value of accruals and consequences for market anomalies. Journal of Accounting, Auditing \& Finance, 27(2), 151-176. https://doi. org/10.1177/0148558x11409149

28. Nguyen, H., \& Nguyen, T. (2020). The prediction of future operating cash flows using accrual-based and cash-based accounting information: Empirical evidence from Vietnam. Management Science Letters, 10(3), 683694. https://doi.org/10.5267/j. msl.2019.9.010

29. Pimentel, R. C., \& Malacrida, M. J. C. (2020). Quarterly earnings, operating cash flow, and accruals in future performance assessment. BAR-Brazilian Administration Review, 17(4). Retrieved from https://bar.anpad.org.br/index. php/bar/article/view/504

30. Ragab, N., \& Hani, E. C. (2018). The Value-Relevance of Operating Cash Flow: Comparative Study of Banks' listed on the Egyptian And Beirut Stock Exchanges. Academy of Accounting and Financial Studies Journal, 22(3), 1-12.

31. Sharawi, H. (2021). Earnings Versus Cash Flows in Predicting Future Cash Flows: Evidence from Egypt and KSA. Alexandria Journal of Accounting Research, 5(1), 714-743.区 Retrieved from https://papers.ssrn. com/sol3/papers.cfm?abstract_ id $=3887423$

32. Shubita, M. (2013). The forecasting ability of earnings and operating cash flow. Interdisciplinary Journal of Contemporary Research in Business, 5(3) 442-456. Retrieved from https://journal-archieves34.webs. com/442-456.pdf

33. Shubita, M. F. (2019). The impact of working capital management on cash holdings of large and small firms: Evidence from Jordan. Investment Management and Financial Innovations, 16(3), 76-86. https://doi.org/10.21511/ imfi.16(3).2019.08

34. Zhou, H., Wang, L., Xia, Q., \& Zhang, S. (2010). Empirical Analysis of Financial Early Warning Based on Cash Flow. International Conference on Information Management and Engineering (ICIME). 